\title{
A 250-item list of Old Chinese vocabulary in the Baxter-Sagart reconstruction ${ }^{1}$
}

Laurent SAGART, CNRS (emeritus), Paris, and MA Kun, Sun Yat-sen University, Guangzhou

Cahiers de Linguistique Asie Orientale 2020, 49: 92-105

\begin{abstract}
A 250-concept list was established for the purposes of a lexically-based study of Sino-Tibetan phylogeny (Sagart et al. 2019). This paper supplies the Old Chinese version of the list, in the Old Chinese reconstruction of Baxter and Sagart 2014. Chinese words attested in pre-Han times were selected based on their meaning as given in major lexica such as the Hànyŭ Dà Zìdiăn. At times more than one OC item was found to match a concept in the list without it being clear which of the terms was the oldest. In such cases all the candidates were retained. As a result, the Old Chinese version of the list contains 301 words.
\end{abstract}

\section{Keywords}

Old Chinese - lexicon - word-lists - basic vocabulary

\section{Résumé}

Une liste de 250 concepts a été établie dans le cadre d'un projet sur la phylogénie sino-tibétaine (Sagart et al. 2019). Cet article présente la liste pour le chinois archaïque, dans la reconstruction de Baxter et Sagart (2014). Elle contient des mots attestés avant l'époque Han, choisis en fonction de leur sens dans les ouvrages lexicographiques de référence tels le Hànyǔ Dà Zìdiăn. Lorsque plusieurs mots chinois correspondaient à l'un des concepts de la liste sans que puisse être établie d'antériorié chronologique entre eux, on a retenu les différents candidats. La liste contient en tout 301 mots.

As part of the preparatory work for a computer-based project on Sino-Tibetan phylogeny (Sagart et al. 2019), a 250-concept vocabulary list was established collaboratively by Johann-Mattis List, Guillaume Jacques and Laurent Sagart, members of the project. Selection of concepts aimed at balancing basicness, semantic coverage, and availability of items in the extant Sino-Tibetan documentation. Most of the items qualify as basic vocabulary, but old and culturally important notions like \#141 'needle', \#165 'rope', \#182 ‘sickle', verbs like \#152 'to plant', were retained. Similarly, terms for animal and plant domesticates like \#151 'pig', \#7 'Tibetan barley' and \#160 'rice plant' were selected because of the potential importance of domestications in population expansions, and of those in the formation of language families (Bellwood 1985; Renfrew 1987). It would have been desirable to include the names of foxtail and broomcorn millet, two early East Asian domesticated cereals widely grown by Sino-Tibetan peoples, but the corresponding terms are only known from a small number of languages. At a later stage in the project, largely to enhance mutual coverage, the list was reduced to 180 items. A database marking cognates for these items in fifty Sino-Tibetan languages can be found at http://dighl.github.io/sinotibetan.

The Old Chinese (OC) version of the 250 list was compiled with reference to the main Chinese lexica such as the 2010

\footnotetext{
${ }^{1}$ Ma Kun's research was funded by the French government Séjours Scientifiques de Haut Niveau (SSHN) project 871429L_FDR.
} 
edition of the Hànyǔ Dà Zìdiăn 漢語大字典 [Hànyǔ Dà Zìdiăn Biānjí Wěiyuánhuì 2010] or Jiăgǔwén zì biān 甲骨文 字 編 [Ľ̌ Zōngkūn 2012]. Since the primary use of the OC list was to serve in our study of Sino-Tibetan (ST) phylogeny, and considering that the OC period ends with the beginning of the Han dynasty in 206 BCE, we aimed to identify the oldest pre-Han Chinese term for each meaning. A word was selected as representative of one of the concepts in our list when it occurred in that meaning in pre-Han texts or palaeography. In one case ('egg'), an unwritten vulgar word without any pre-Han occurrences was included without any kind of written evidence, on the basis of its presence in three southern Chinese dialects at least (fn.2), with regular correspondences. The word, reconstructable as $* \mathrm{t}^{\mathrm{h}} \mathrm{u}[\mathrm{r}]$, was selected alongside the better-known form 卵 *k.r or? >lwanX $>$ luăn 'egg', because it matches the 'Tibeto-Burman' (TB) word (reconstructed as *twiy 'egg' by Benedict 1972; compare 水 *s.tur? > sywijX > shuĭ 'water; river'; PTB (Benedict) *twiy 'water'). The lack of a Chinese character to write * $\mathrm{t}^{\mathrm{h}} \mathrm{u}[\mathrm{r}]$ is thought to be due to the fact that the word also designates the testicles.

In a number of cases it was not obvious which of the Chinese forms was the oldest: in such cases we retained several competing forms for the same concept. Thus we give six forms for \#76 'good'; five for \#26 'cold'; four for \#158 'red'; three for \#73 'full', \#90 'high/tall', \#99 'to hunt', \#188 'small', etc. At the same time a satisfactory OC form for a few notions could not be found: \#7 'Tibetan barley', \#105 'to knead', \#144 'the nit', \#181 'shy', \#230 'we [first person plural inclusive]', \#248 ‘you [second person plural]'. Plural personal pronouns did not exist in OC. A word for 'Tibetan barley' could not be found because although barleys were known in China in OC times, Tibetan barley shows an adaptation to highland environments and this particular kind of barley was not named by the Chinese. It is possible that 'nit' was a compound such as 'louse egg'; but if so, we are uncertain what the word for 'egg' in it may have been.

We list the Old Chinese equivalent of the 250 concepts according to the alphabetical order of concepts. OC forms are in the Baxter and Sagart (2014) system. All the words except for 杖 'the stick', 冷 'cold' and 窄 'narrow', were reconstructed as part of the Version 1.1 release of September 2014 (http://ocbaxtersagart.lsait.lsa.umich.edu/). Reconstructions for the remaining three words are provided below. The character 窄 'narrow' is late; the word

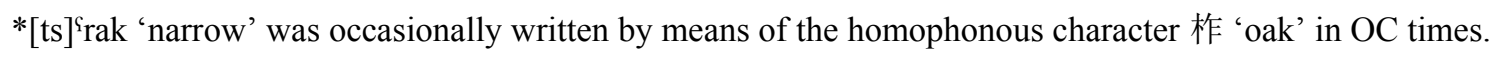

the stick

cold

杖 *m-[t]ran? $>$ drjangX $>$ zhàng

narrow

冷 *[r] $]^{\mathrm{S} e n ?}>$ lengX $>$ lěng

窄 $*[\text { ts }]^{\text {' rak }}>$ tsraek $>$ zhăi 'narrow'

Due to the existence of competing forms for single concepts and to the lack of Chinese equivalents for certain notions, the total number of OC reconstructed forms in our list is 301. A Chinese character is available for all but one: corresponding to the notion 'egg', we have added a second form next to 卵 *k. $\mathrm{r}^{\mathrm{r}} \mathrm{or}$ ?, as already mentioned: that form reconstructs as $\mathrm{OC} *^{\mathrm{h}} \mathrm{t} \mathrm{u}[\mathrm{r}]$ and in the modern dialects where it occurs ${ }^{2}$ is homophonous with 春 $*^{\mathrm{h}} \mathrm{un}>t \operatorname{syh} w i n>$ chūn 'springtime'. This is an unwritten vulgar form which refers both to eggs and testicles. We believe this is the original word for 'egg', and that it was displaced by the standard term 卵 *k.r. or?, a polite form probably somehow related to 果 $*[\mathrm{k}]]^{\mathrm{S}} \mathrm{O}[\mathrm{r}]$ ? 'fruit; result'.

Because the notions in this list were not selected specifically for Chinese, at times the closest OC equivalent for a notion is a word whose main meaning is not strictly identical with that notion. For instance \#32 'the daughter' is given as 女

\footnotetext{
${ }^{2}$ Cantonese t thoen 1 'egg' $<* \mathrm{t}^{\mathrm{h}} \mathrm{u}[\mathrm{r}]$ (cp. t/hœen 1 'spring'); Hakka (Meixian, Lufeng) t/hun 1 'eggs of birds, reptiles; roe of fish' (cp. tfhun 1 'spring'); Yizhang 宜章 patois sei 1 'egg' (cp. sei 1 'spring'); and other locations in Guangzhou, Jiangxi and Guangxi.
} 
*nra?, but that word more generally means 'woman, female', although it is at times specifically used as 'daughter'.

Gloss

above

all

all

all

the ant

the ant

the armpit

bad

the bamboo

the barley (tibetan or highland)

to be alive

the belly

10 below, under

11 big

12 the bird

13 to bite

14 black

14 black

15 the blood

16 to blow (of wind)

17

18

19

20

21

22

23 the body hair (hair or fur)

the bone

the branch

the breast (female)

to burn [intransitive]

to buy

to chew

the child (young human)

the cloud

cold (of temperature)

cold (of temperature) cold (of temperature)

cold (of temperature)

cold (of temperature)

to come

correct (right)

correct (right)

to count

to weep

dark

the daughter

the dew

to die

to dig

to dig

dirty

the dog
OC (Baxter and

Sagart, v. 1.1.)

*dan?-s

* $[\mathrm{g}]^{\mathrm{S}} \mathrm{r}[\partial] \mathrm{m}$

$*[\mathrm{~b}] \mathrm{rom}$

${ }^{*} \mathrm{k}^{\uparrow} \mathrm{rij}$

$* \mathrm{q}^{\mathrm{hS}}(\mathrm{r}) \mathrm{o}$ ?

*m-qh(r)aj?

* [G](r)Ak

* 个ak

*truk

*srey

* p(r)uk

* gra?

*1 $\mathrm{a} a[\mathrm{t}]-\mathrm{s}$

$*^{t}$ in?

$*[\mathrm{~d}] \mathrm{e}[\mathrm{t}]-\mathrm{s}$

* m ¡ $ә \mathrm{k}$

$*$ [ts]rə

* mis ik

$* \mathrm{t}^{\mathrm{h}} \mathrm{O}[\mathrm{r}]$

*C.m ${ }^{\text {`aw }}$

${ }^{*} \mathrm{k}^{\mathrm{S}} \mathrm{ut}$

*ke

*no?

*C.na[n]

*mraj?

* [dz] ewk-s

*ye

$*[\mathrm{G}]^{\mathrm{w}} \partial[\mathrm{n}]$

$*[\mathrm{r}]^{\mathrm{s} e j}$ ?

*Co.[g] $\mathrm{a}$ [n]

*C.ray

* $\left[\mathrm{ts}^{\mathrm{h}}\right]^{\mathrm{f}} \mathrm{a}$

$*\left[\mathrm{ts}^{\mathrm{h}}\right] \mathrm{en}-\mathrm{s}$

*mə.r ${ }^{\mathrm{r}} \partial \mathrm{k}$

*trey

*ten-s

*s-ro?

*k-rəp

* q⿳um-s

*nra?

*p.ríak-s

* sij?

* $[\mathrm{g}]^{\mathrm{\varsigma}} \mathrm{ut}$

*[g]ot, *[g]ut

* q ${ }^{\mathrm{wS}} \mathrm{ra}$

$*[\mathrm{k}]^{\mathrm{wh}}[\mathrm{e}][\mathrm{n}]$ ?
Notes

Also 'to be born'/'to give birth', the primary meaning

Also 'milk'

See \#96 'hot'

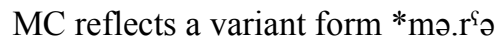

May have to be amended to $* t<r>$ en in view of the probable word-family relationship to 正 below.

More generally 'woman, female' (\# 242) 


\begin{tabular}{|c|c|c|c|c|}
\hline 38 & the dream & 夢 & *C.məy-s & \\
\hline 39 & to drink & 飲 & $* \mathrm{q}(\mathrm{r})[\mathrm{u}] \mathrm{m} ?$ & \\
\hline 40 & dry & 乾 & $*[\mathrm{k}]^{\mathrm{s}} \mathrm{ar}$ & \\
\hline 41 & the dust & 塵 & $*[\mathrm{~d}] \mathrm{r} \partial[\mathrm{n}]$ & \\
\hline 42 & the ear & 耳 & *C.nə? & \\
\hline 43 & early & 早 & ${ }^{*}$ Na.ts ${ }^{\varsigma} u ?$ & \\
\hline 44 & the earth (soil) & 土 & $* \mathrm{t}^{\mathrm{hS}} \mathrm{a} ?$ & \\
\hline 45 & the earthworm & 螾 & $*[\mathrm{G}](\mathrm{r}) \mathrm{\partial}[\mathrm{r}] ?$ & \\
\hline 46 & to eat & 食 ～～ & *mə-lək & \\
\hline 47 & the egg & (no char.) & $* \mathrm{t}^{\mathrm{h}} \mathrm{u}[\mathrm{r}]$ & see fn. 1 . \\
\hline 47 & the egg & 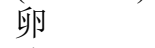 & ${ }^{*} \mathrm{k} . \mathrm{r}^{\mathrm{f}}$ or? & \\
\hline 48 & eight & 八 & $*^{\mathrm{f}}$ ret & \\
\hline 49 & the eye & 目 & ${ }^{*} \operatorname{C} . \mathrm{m}(\mathrm{r})[\mathrm{u}] \mathrm{k}$ & \\
\hline 50 & far & 遠 & *C. $\mathrm{G}^{\mathrm{w}}$ an? & \\
\hline 51 & the father & 父 & $*[\mathrm{~N}-\mathrm{p}](\mathrm{r}) \mathrm{a} ?$ & \\
\hline 52 & the feather & 羽 & $*[\mathrm{G}]^{\mathrm{w}}(\mathrm{r}) \mathrm{a} ?$ & \\
\hline 53 & to fight & 鬥 & $*_{t^{\mathrm{s}}}^{\mathrm{s}} \mathrm{k}-\mathrm{s}$ & \\
\hline 54 & the fire & 火 & $*\left[\mathrm{q}^{\mathrm{wh}}\right]^{\mathrm{f}} \partial j ?$ & The initial could be *m-. \\
\hline 55 & firewood & 薪 & $*[\mathrm{~s}] \mathrm{i}[\mathrm{n}]$ & \\
\hline 56 & the fish & 魚 & $*[\mathrm{r} . \mathrm{n}] \mathrm{a}$ & \\
\hline 57 & five & 五 & $*^{*}$ C. $\eta^{\complement} a ?$ & \\
\hline 58 & the flea & 蚤 & $*_{\mathrm{ts}}^{\mathrm{\complement}} \mathrm{u} ?$ & \\
\hline 59 & to float & 泛 & $* \mathrm{p}^{\mathrm{h}}(\mathrm{r})[\mathrm{o}] \mathrm{m}-\mathrm{s}$ & \\
\hline 59 & to float & 浮 & $*_{\mathrm{m}} \mathrm{b}(\mathrm{r}) \mathrm{u}$ & \\
\hline 59 & to float & 游 & $*[\mathrm{~N}-] \mathrm{ru}$ & \\
\hline 60 & to flow & 流 & $*$ ru & \\
\hline 61 & the flower & 華 & $* N-q^{\text {whs }}$ ra & \\
\hline 62 & to fly (move through air) & 飛 & *Cə.pə[r] & \\
\hline 63 & the fog & 霧 & *kə.m(r)[o]k-s & \\
\hline 64 & the foot & 足 & $*[\mathrm{ts}] \mathrm{ok}$ & \\
\hline 64 & the foot & 脚 & $*[\mathrm{k}] \mathrm{ak}$ & \\
\hline 65 & the forest & 林 & $*[\mathrm{r}] \partial \mathrm{m}$ & \\
\hline 66 & to forget & 忘 & $*$ man & Cognate with 亡 *man 'flee; disappear; die'. \\
\hline 67 & four & 四 & $*_{\text {s.li }}[\mathrm{j}]-\mathrm{s}$ & \\
\hline 68 & the fox & 狐 & $*[\mathrm{~g}]^{\mathrm{wS}} \mathrm{a}$ & \\
\hline 69 & the frog & 龜 & ${ }^{*} \mathrm{q}^{\mathrm{wS}} \mathrm{re}$ & Onomatopoeia \\
\hline 70 & the front (front side) & 前 & $*[\mathrm{dz}]^{\mathrm{S}} \mathrm{en}$ & \\
\hline 71 & the frost & 霜 & $*[\mathrm{~s}] \mathrm{ray}$ & \\
\hline 72 & the fruit & 實 & $*_{\text {mo.li }[\mathrm{t}]}$ & \\
\hline 73 & full & 充 & $* t^{\text {h }}$ un & \\
\hline 73 & full & 滿 & $* \mathrm{~m}^{\mathrm{\varphi}}[\mathrm{o}][\mathrm{n}] ?$ & \\
\hline 73 & full & 盈 & $* \operatorname{leg}(<* \operatorname{lin} ?)$ & \\
\hline 74 & to give & 界 & $*_{\mathrm{pi}}[\mathrm{t}]-\mathrm{s}$ & \\
\hline 75 & the goat & 羊 & $*_{\text {Gay }}$ & \\
\hline 76 & good & 好 & $* \mathrm{q}^{\mathrm{hS}} \mathrm{u}$ ? & \\
\hline 76 & good & 嘉 & $* \mathrm{k}^{\complement}<\mathrm{r}>\mathrm{aj}$ & \\
\hline 76 & good & 藏 & $*[\mathrm{ts}]^{\mathrm{f}} \mathrm{a \eta}$ & \\
\hline 76 & good & 良 & $*[\mathrm{r}] \mathrm{an}$ & \\
\hline 76 & good & 佳 & $*[\mathrm{k}]^{\mathrm{c}} \mathrm{re}$ & \\
\hline 76 & good & 善 & $*[\mathrm{~g}] \mathrm{e}[\mathrm{n}] ?$ & \\
\hline 77 & the grass & 薦 & ${ }^{*}$ Co.ts ${ }^{\complement} \partial[\mathrm{r}]-\mathrm{s}$ & \\
\hline 77 & the grass & 草 & $*\left[\mathrm{ts}^{\mathrm{h}}\right]^{\mathrm{S}} \mathrm{u} \mathrm{P}$ & \\
\hline 78 & green & 綠 & *pə.rok & \\
\hline 78 & green & 蒼 & $*\left[\mathrm{ts}^{\mathrm{h}}\right]^{\mathrm{f}} \mathrm{a \eta}$ & \\
\hline 79 & the hail & 霰 & $*^{\mathrm{S}}[\mathrm{e}] \mathrm{r}-\mathrm{s}$ & \\
\hline 79 & the hail & 雹 & ${ }^{*} \mathrm{C} .[\mathrm{b}]^{\mathrm{S}}$ ruk & \\
\hline 80 & the hair (of the head) & 髮 & *pot & \\
\hline 81 & the hand & 手 & $*_{\text {nou? }}$ & \\
\hline 82 & hard & 堅 & ${ }^{*} k^{\complement} i[y]$ & \\
\hline 82 & hard & 剛 & ${ }^{*} k^{\varsigma}$ an & \\
\hline 83 & $\begin{array}{l}\text { he or she [third person } \\
\text { singular] }\end{array}$ & 其 & $*_{\mathrm{g} \partial}$ & Also plural \\
\hline
\end{tabular}


he or she [third person singular] the head the head to hear the heart heavy here to hide (conceal) to hide (conceal) high / tall high / tall high / tall to hold to hold the hoof horizontal the horn (keratinized skin) 角 the horse hot the house hundred to hunt to hunt to hunt the husband I [first person singular] the ice inside to kill to knead the knee knife to know (something) the lake late to laugh the leaf to learn left to lick to lie down light (of weight) the lip (the lips) the liver long the louse the lung the man (male human) many to marry (a man marries a woman) the meat middle middle the moon morning the mosquito the mother the mountain *to

*lu?

$*[\mathrm{y}] \mathrm{o}[\mathrm{r}]$

*mu[n]

*səm

$* \mathrm{~N}-\mathrm{t}<\mathrm{r}>\mathrm{O}$ ?

$*\left[\mathrm{ts}^{\mathrm{h}}\right] \mathrm{e}(\mathrm{j})$ ?

*nr[ə]k

*[?](r)ə[n]?

*t'rawk

*Co.[k] $]^{\text {Saw }}$

*[N-k](r)aw

$*[\mathrm{t}]$ ip

$*[\mathrm{~d}] \mathrm{r} \partial$

* t个ek

*C.gws ran

*C. [k] $]^{\mathrm{S}}$ rok

${ }^{*}$ m ${ }^{\text {r }}$ ?

${ }^{*}$ C.nat

${ }^{*} \mathrm{q}^{\mathrm{S}} \mathrm{ok}$

*p prak

*s.tu?-s

*r[a]p

*lín

*p(r)a

$* y^{\text {ৎa }}$

*p.rəy

$* n^{\complement}[\mathrm{u}] \mathrm{p}-\mathrm{s}$

$*_{s}<r>$ at

$*_{\text {s-tsik }}$

${ }^{*}$ C.t t $^{\text {aw }}$

*tre

* $[\mathrm{g}]^{\mathrm{s} a}$

*m[o][r]?

*[s-1] aw-s

*1[a]p

*m-k ${ }^{\varsigma}$ ruk

*ts $\mathrm{a}$ [ jj]?

*Co.le?

*[y] $[\mathrm{o}] \mathrm{j}-\mathrm{s}$

$*\left[\mathrm{k}^{\mathrm{h}}\right] \mathrm{en}$

*sə.dur

* s. $k^{\mathrm{h} a}[\mathrm{r}]$

*Co-[N]-tray

$*_{\text {srik }}$

$* \mathrm{p}^{\mathrm{h}} \mathrm{O}[\mathrm{t}]-\mathrm{s}$

$*^{\mathrm{q}}[\mathrm{\partial}] \mathrm{m}$

*[t.1] aj

$*[\mathrm{ts}]^{\mathrm{h}} \mathrm{O}$ ?-s

*k.nuk

*?ay

*truy

*[y] wat

*[d]ər

*C.mə[r]

*mo?

*s-prar
Object pronoun. Also plural

The main word in this meaning

Also 'this'

Related to 喬 below.

A loan from a more westerly ST language, see Sagart et. al. 2019.

Related to 獸 *s.th $\mathrm{u}($ ?)-s '(wild) animal'

Cognate with 田*1'in 'field'

Also 'adult man', the original meaning

Related to 入 *n[u]p 'enter'

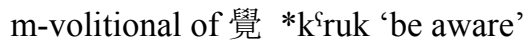

Also 'to assist', the primary meaning

Etymologically from 取 *ts ${ }^{\mathrm{h}} \mathrm{o}$ ' take' 


\begin{tabular}{|c|c|c|c|c|}
\hline 133 & the mouse or rat & 鼠 & $*[1] \mathrm{a} ?$ & \\
\hline 134 & the mouth & 口 & ${ }^{*} \mathrm{k}^{\mathrm{hS}}(\mathrm{r}) \mathrm{o} ?$ & \\
\hline 135 & the mud & 泥 & ${ }^{*} \mathrm{C} . \mathrm{n}^{\mathrm{S}}[\mathrm{\partial j}]$ & \\
\hline 136 & $\begin{array}{l}\text { the nail (fingernail or } \\
\text { claw) }\end{array}$ & 叉 & $*[\mathrm{ts}]^{\mathrm{c}<\mathrm{r}>\mathrm{u} ?}$ & \\
\hline 137 & the name & 名 & *C.men & \\
\hline 138 & narrow & 柞=窄 & $*[\mathrm{ts}]^{\mathrm{S}} \mathrm{rak}$ & \\
\hline 138 & narrow & 狹 & $* \mathrm{~N}-\mathrm{k}^{\mathrm{f}}<\mathrm{r}>\mathrm{ep}$ & $\begin{array}{l}\text { Cognate with 挾 } * \mathrm{~m}-\mathrm{k}^{\mathrm{f}} \mathrm{ep} \text { 'clasp', 梜 } \\
* \mathrm{C} . \mathrm{k}^{\mathrm{\varsigma}<\mathrm{r}>\mathrm{ep}} \text { 'chopsticks', etc. }\end{array}$ \\
\hline 139 & near & 邇 & $*_{\mathrm{n}}[\partial][\mathrm{r}] ?$ & \\
\hline 139 & near & 近 & *N-kər? & \\
\hline 140 & the neck & 脰 & *kə.d $d^{\mathrm{f}} \mathrm{ok}-\mathrm{s}$ & \\
\hline 140 & the neck & 領 & $*[\mathrm{r}] \mathrm{en} ?$ & \\
\hline 141 & the needle (for sewing) & 箴 & $*_{\mathrm{t}}[\mathrm{k}] \partial \mathrm{m}$ & \\
\hline 142 & new & 新 & $*^{*}$ s.ts ${ }^{\mathrm{h}} \mathrm{i}[\mathrm{n}]$ & \\
\hline 143 & nine & 九 & $*[\mathrm{k}] \mathrm{u} ?$ & \\
\hline 144 & the nit & & & \\
\hline 145 & noon & 午 & $*[\mathrm{~m}] . \mathrm{q}^{\mathrm{hS}} \mathrm{a} ?$ & $\begin{array}{l}\text { A cyclical sign in the Shang oracular } \\
\text { inscriptions, acquiring the meaning 'noon' in } \\
\text { late Zhou. }\end{array}$ \\
\hline 146 & the nose & 鼻 & $*^{m}$-bi $[t]-s$ & \\
\hline 147 & old (of person) & 老 & ${ }^{*}$ C.r. ${ }^{\mathrm{f}} \mathrm{u}$ ? & \\
\hline 148 & one & 一 & $*$ Pi $[\mathrm{t}]$ & \\
\hline 149 & the otter & 獺 & $\left.{ }^{*} r_{0}{ }^{\complement} a t, *[\mathrm{~m}-\mathrm{r}]\right]^{\mathrm{C}} \mathrm{at}$ & \\
\hline 150 & outside & 外 & $*[\mathrm{n}]{ }^{\mathrm{wS}} \mathrm{a}[\mathrm{t}]-\mathrm{s}$ & \\
\hline 151 & the pig & 豕 & *laj? & \\
\hline 152 & to plant (vegetals, rice) & 栽 & $*[\mathrm{ts}]^{\varsigma} \partial$ & \\
\hline 152 & to plant (vegetals, rice) & 種 & *(mo-)ton?-s & \\
\hline 153 & to play & 玩 & $*[\mathrm{y}]^{\mathrm{S}} \mathrm{O}[\mathrm{n}]-\mathrm{S}$ & \\
\hline 154 & to pull & 抴 & $* 1[\mathrm{a}] \mathrm{t}$ & \\
\hline 155 & to push & 推 & $* \mathrm{t}^{\mathrm{hS}} \mathrm{uj}$ & \\
\hline 156 & the rain & 雨 & ${ }^{*} \mathrm{C} . \mathrm{G}^{\mathrm{w}}(\mathrm{r}) \mathrm{a} ?$ & \\
\hline 157 & the rainbow & 虹 & ${ }^{*} \mathrm{~m}-\mathrm{k}^{\mathrm{s}}$ on, ${ }^{*} \mathrm{k}^{\mathrm{s}}$ ron-s & \\
\hline 158 & red & 朱 & $*$ to & \\
\hline 158 & red & 䞓 & $*_{\mathrm{t}-\mathrm{k}^{\mathrm{h}} \mathrm{ren}}$ & \\
\hline 158 & red & 䑣 & $* \mathrm{~N}-\mathrm{r}^{\mathrm{C}} \mathrm{u}[\mathrm{m}]$ & \\
\hline 158 & red & 赤 & $*\left[\mathrm{t}-\mathrm{q}^{\mathrm{h}}\right](\mathrm{r}) \mathrm{Ak}$ & \\
\hline 159 & to reside (live) & 宅 & $*_{\mathrm{m}}-\mathrm{t}^{\mathrm{f}}<\mathrm{r}>\mathrm{ak}$ & \\
\hline 160 & the rice plant & 稻 & $*[1]^{\varsigma} \mathrm{u} ?$ & \\
\hline 161 & right & 右 & $*[\mathrm{G}]^{\mathrm{w}} \partial ?$ & \\
\hline 162 & the river & 水 & *s.tur? & Also 'water', see \# 229 \\
\hline 163 & the road & 路 & *Co.r. ${ }^{\mathrm{f}}$ ak-s & \\
\hline 164 & the root & 根 & $*[\mathrm{k}]^{\mathrm{C}} \partial[\mathrm{r}]$ & \\
\hline 165 & the rope & 繩 & *Co-m.rəy & \\
\hline 166 & round & 圓=回 & $*_{\mathrm{G}^{\mathrm{w}}}<\mathrm{r}>\mathrm{en}$ & \\
\hline 167 & to run & 走 & $*[\mathrm{ts}]^{\mathrm{f}} \mathrm{O} ?$ & \\
\hline 167 & to run & 奔 & $*^{*} p^{\varsigma} u r$ & \\
\hline 168 & the salt & 鮮 & $* N-[t s]^{\mathrm{Y}} \mathrm{aj}$ & \\
\hline 168 & the salt & 鹽 & $*[\mathrm{Gr}][\mathrm{o}] \mathrm{m}$ & \\
\hline 169 & salty & 鹹 & ${ }^{*} \mathrm{Co} \cdot[\mathrm{g}]^{\mathrm{s}} \mathrm{r}[\mathrm{o}] \mathrm{m}$ & \\
\hline 170 & the sand & 沙 & $*_{s}{ }^{\uparrow}$ raj & \\
\hline 171 & to scratch & 搔 & $*_{\mathrm{s}-}[\mathrm{ts}]^{\mathrm{s}} \mathrm{u}$ & \\
\hline 172 & the sea & 海 & $* m^{\uparrow} ว ?$ & \\
\hline 173 & to see & 見 & $*[\mathrm{k}]^{\mathrm{f}} \mathrm{en}-\mathrm{s}$ & \\
\hline 174 & the seed & 種 & *k.ton? & \\
\hline 175 & seven & 七 & $*\left[\mathrm{ts}^{\mathrm{h}}\right] \mathrm{i}[\mathrm{t}]$ & Possibly *s.no $[\mathrm{t}]$ \\
\hline 176 & sharp & 利 & ${ }^{*}$ C.ri $[\mathrm{t}]-\mathrm{s}$ & \\
\hline 177 & the sheep & 羊 & $*_{\text {Gan }}$ & \\
\hline 178 & to shoot (an arrow) & 射 & *Co.lAk-s & \\
\hline 179 & short & 短 & $* \mathrm{t}^{\mathrm{f}}$ or? & \\
\hline 180 & the shoulder & 肩 & $*[\mathrm{k}]^{\mathrm{S}} \mathrm{e}[\mathrm{n}]$ & \\
\hline
\end{tabular}




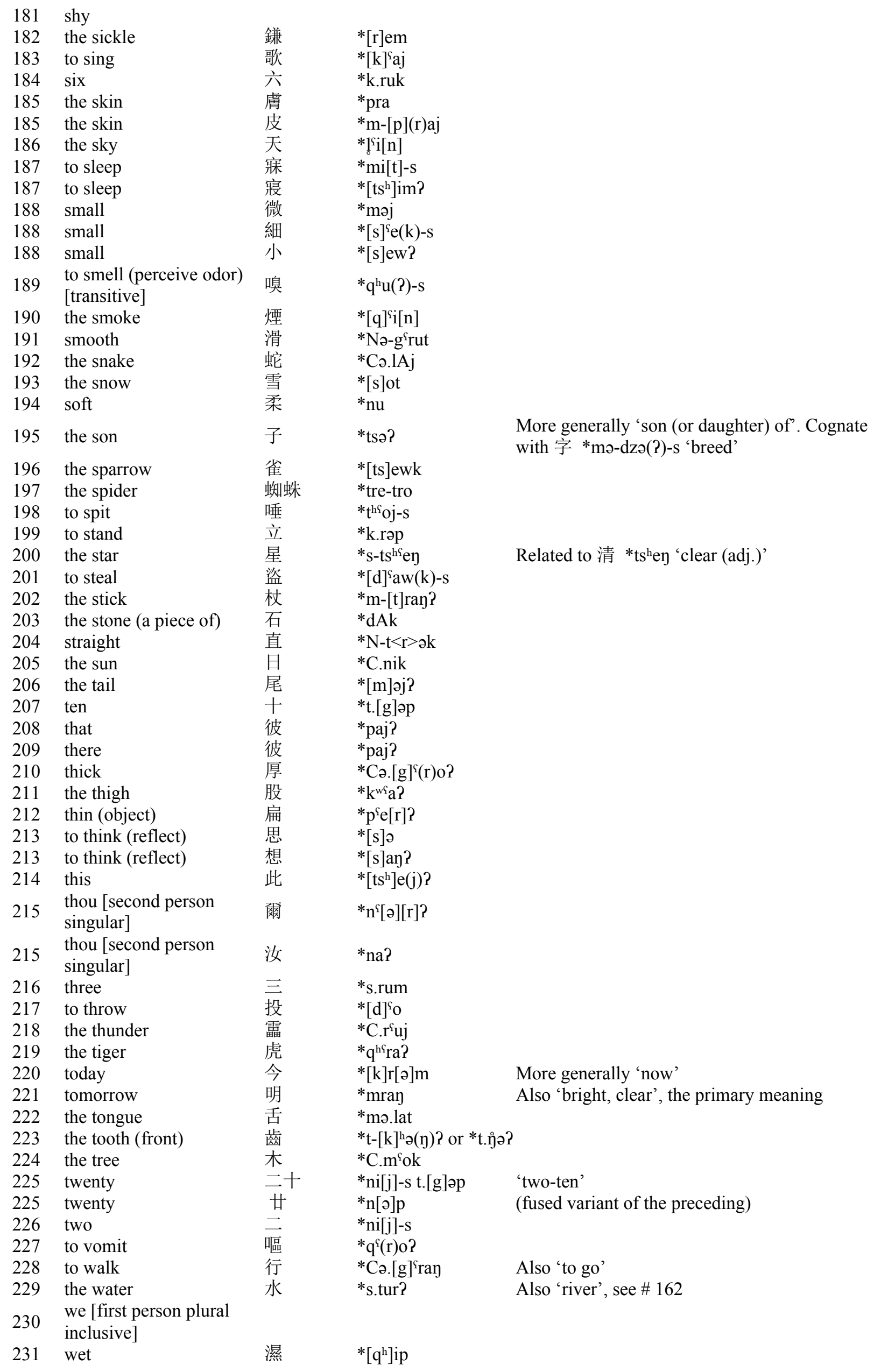




\begin{tabular}{|c|c|c|c|c|}
\hline 232 & what & 何 & $*[\mathrm{~g}]^{\mathrm{c}} \mathrm{aj}$ & \\
\hline 232 & what & 胡 & $*[\mathrm{~g}]^{\mathrm{f}} \mathrm{a}$ & Perhaps a reduced form of the preceding \\
\hline 233 & the wheat & 麥 & $*_{\mathrm{m}}$-r $\mathrm{r}^{\mathrm{r}} \mathrm{k}$ & \\
\hline 234 & where & 爱 & $*_{\mathrm{G}^{\mathrm{W}}} \mathrm{a}[\mathrm{n}]$ & \\
\hline 235 & white & 白 & $* b^{\varsigma}$ rak & Also 'clear', the original meaning \\
\hline 236 & who & 誰 & $*[d] u j$ & \\
\hline 237 & the wife & 婦 & *mə.bə? & \\
\hline 237 & the wife & 妻 & $*\left[\mathrm{ts}^{\mathrm{h}}\right]^{\complement} \partial \mathrm{j}$ & \\
\hline 238 & the wind & 風 & *prəm & \\
\hline 239 & the wing & 翅 & $*_{\mathrm{s}}-\mathrm{k}^{\mathrm{h}} \mathrm{e}-\mathrm{s}$ & \\
\hline 240 & to wipe & 拭 & *lok & \\
\hline 241 & the wolf & 狼 & $*[r]^{\text {fan }}$ & \\
\hline 242 & the woman & 女 & *nra? & See \# 32 'daughter’ \\
\hline 243 & the wood (material) & 材 & $*[\mathrm{dz}]^{\mathrm{\varsigma}} \partial$ & \\
\hline 244 & $\begin{array}{l}\text { to sow (broadcast, scatter } \\
\text { seeds) }\end{array}$ & 播 & * $p^{\text {`ar-s }}$ & \\
\hline 245 & the year & 年 & $*$ C.n $n^{\mathrm{i}} \mathrm{i}[\mathrm{y}]$ & Also 'harvest', the primary meaning \\
\hline 246 & yellow & 黃 & ${ }^{*} \mathrm{~N}-\mathrm{k}^{\mathrm{w}}$ an & Cognate with 光 $* \mathrm{k}^{\mathrm{wS}}$ an 'light, brightness' \\
\hline 247 & yesterday & 昨 & $*[\mathrm{dz}]^{\mathrm{S}} \mathrm{ak}$ & \\
\hline 248 & $\begin{array}{l}\text { you [second person } \\
\text { plural] }\end{array}$ & & & \\
\hline 249 & young & 幼 & *[?](r)iw-s & \\
\hline 250 & the shit & 屎 & $*\left[\mathrm{q}^{\mathrm{h}}\right] \mathrm{ij} ?$ & \\
\hline
\end{tabular}

\section{References}

Baxter, William H. and Laurent Sagart. 2014. Old Chinese: a new reconstruction. New York: Oxford University Press. Benedict, Paul K. 1972. Sino-Tibetan: a Conspectus. Cambridge: University Printing House.

Bellwood, Peter. 1985. Prehistory of the Indo-Malaysian Archipelago. North Ryde: Academic.

Hànyǔ Dà Zìdiăn Biānjí Wěiyuánhuì 漢語大字典編輯委員會 [Hànyǔ Dà Zìdiăn Editorial committee]. 2010. Hànyǔ Dà Zìdiăn 漢語大字典 [Great character dictionary of the Chinese language], 2nd edition in nine volumes. Wǔhàn 武 漢: Húběi Chángjiāng publishing group, Chóngwén Shūjú publishing group; Sìchuān Císhū Chūbănshè 湖北長江出 版社集團；崇文書局四川出版社集團；四川辭書出版社.

Lǐ Zōngkūn 李宗焜. 2012. Jiăgǔ Wénzibiān 甲骨文字編 [Collection of oracle-bone inscriptions]. 北京：Běijīng： Zhōnghuá Shūjú 中華書局.

Renfrew, Colin. 1987. Archaeology and Language. London: Jonathan Cape.

Sagart, Laurent, Guillaume Jacques, Yunfan Lai, Robin J. Ryder, Valentin Thouzeau, Simon J. Greenhill, JohannMattis List. 2019. Dated language phylogenies shed light on the ancestry of Sino-Tibetan. Proceedings of the National Academy of Sciences May 2019, 116 (21) 10317-10322; DOI: 10.1073/pnas.1817972116. 